\title{
"A STUDY ON IMPACT OF EURO CURRENCY ON GOLD PRICE IN INDIAN COMMODITY MARKET"
}

\begin{tabular}{|c|c|}
\hline $\begin{array}{c}\text { Bindu S } \\
\text { Assistant Professor, } \\
\text { Dept. of Commerce and Management, } \\
\text { RNS First Grade College, Channasandra, } \\
\text { Bengaluru-560098 } \\
\text { bindiadhumbi@ yahoo.co.in }\end{array}$ & $\begin{array}{c}\text { Sudheer Pai K L } \mathbf{~}^{2} \\
\text { Principal,RNS First Grade College, } \\
\text { Channasandra, } \\
\text { Bengaluru-560098 } \\
\text { spkl@ rediffmail.com }\end{array}$ \\
\hline
\end{tabular}

\begin{abstract}
In the present day of financial markets, investment has become more complicated. Risk is a characteristic feature of all commodities. Prices of all commodities are subject to fluctuation over the time in keeping with prevailing demand and supply conditions. This makes the market more volatile. Volatility of commodity market is more, which is usually caused by one of the factors called currency fluctuation. Commodity price fluctuations affect the investor's wealth creation. In this context, the present study is undertaken. Similarly, price of the gold changes continuously due to the fluctuations in Euro currencies. Those who are charged with the responsibility of managing money, their own or others are therefore continuously constantly exposed to risk. This paper aims to find out whether they have a direct or inverse relationship among precious metal Gold and Euro Currency. An investor can make use of this study to make prudent investment in commodities based on the relationship between exchange rates and commodity. The study helps user to take decision regarding investment on gold at right time.
\end{abstract}

Key words: Commodity, Currency, Growth of Euro Currency, Return on Gold Price, Correlation between Euro Currency and Gold

\section{I.INTRODUCTION}

One of the definitions of intermediate generality is that a currency is a system of money (monetary units) in common use, especially in a nation. Under this definition, British pounds, U.S. dollars and European Euros are different types of currencies. Currencies in this definition need not be physical objects, but as stores of value are subject to trading between nations in foreign exchange markets, which determine the relative values of the different currencies.
The euro came into existence on 1 January 1999, although it had been a goal of the European Union (EU) and its predecessors since the 1960s. After tough negotiations, particularly due to opposition from the United Kingdom, the Maastricht Treaty entered into force in 1993 with the goal of creating economic and monetary union by 1999 for all EU states except the UK and Denmark. Any product that can be used for commerce or an article of commerce which is traded on an authorized commodity 
exchange is known as commodity. In MultiCommodities like Bullion (Gold) is traded on day to day basis.

Gold is one of the most highly-sought precious metals in the world. It is used in jewelry, electronics, and coinage. Gold is widely considered to be an effective hedge against inflation, which means that when the dollar depreciates, demand for gold increases. Gold has been used as money for more than 3,500 years as it doubles as a currency and a store of value. Gold is one of very few assets that is not the obligation of someone else. It has also proven to be a good hedge as inflation since the experiments with unbaked fiat money began in Europe and the USA in the 18th century.

\section{Review of Literature}

Gold also appears sensitive to news related to supply and demand. In particular, some studies indicate that Central Bank announcements regarding sales of gold reserve have tended to cause price declines. See Cai, Cheung and Wong (2001) other studies have found that gold's sensitivity to news varies through time, with Hess, Huang and Niessen(2008) presenting evidence that is dependent upon the State of economic with sensitivity increasing during recession. Ehrmann and Fratzsher (2005) focused on the Euro-Dollar exchange rates and found that US news tended to have more of an effect on the exchange rate than German news.

Bose (2008) analyses the information flow, market integration and correlation between commodity futures indices and equity indices and hedge effectiveness of commodity futures indices in India. She utilizes the national indices constructed by MCX India to empirically analyze the above issues. Her analysis indicates that the national commodity indices behave like the equity indices in terms of efficiency and flow of information and confirm that both contemporaneous futures and spot process contribute the price discovery and the futures market can provide information for current spot prices and thus help to reduce volatility in the spot prices of the relevant commodities and provide for effective hedging of price risk.

A study was conducted using regression on changes in gold price against the gold fund index return lagged one month which yield a positive co-efficient, suggestion that at least 
ELK

Asia Pacific Journals

on a short term basis the process of the gold related equities tend to lead bullion prices. Further impact of investor confidence, decision and speculation in gold was undertaken as there is raise in economic confidence and good performance of high yield from bond (Bartolommeo, 1993. In short run gold stocks can be better option and in long run gold as commodity can be better source to hedge portfolio(Le and Chang 2011). The gold price exhibited highly correlated behavior with extreme outliers such as breakdown of governance war or disasters. These rising gold price in particular can be attributed atleast in part to the announcement of the central bank and the event had little relationships, if any at all, with economic cycles in contrast to other commodities, making the worth considering as a gold portfolio diversifiers (Lawrence,2003).

\section{However present study focuses on the} following issues:

Impact of Euro Currency on Gold price in Indian Commodity Market

To find whether they have a direct or inverse relationship among precious metal and gold with Euro
ELK Asia Pacific Journals - Special Issue

ISBN: 978-81-930411-5-4

Since there are problems associated with volatility of commodity market in Gold, the study can help the investors to take rational decisions regarding buying or selling of commodities

\section{Objectives and Scope of the study}

\subsection{Objectives}

To study the behavior of Euro Currency

To ascertain the risk and return on precious metal Gold and Euro

To determine the relationship that exists between the major currencies and precious metal

To measure and quantify the level of financial risk within an Investment portfolio over a specific time frame (VAR)

\subsection{Scope of the Study}

The study is based on availability of data and time period

The study aids an investor to know the impact of currency fluctuations on commodities

Study will also help to know the price variability of commodity in 
ELK

Asia Pacific Journals

relation to major currency such as

rupee-euro

The Euro currency has a greater influence in the appreciation and depreciation on the prices of the commodities

\section{Research Methodology}

4.1 Exploratory research: It is a form of research conducted for a problem that has not been clearly defined. Exploratory research helps to determine the best research design, data collection method and selection of subjects.

Primary Data: Personal discussion was made with the unit manager and interaction with other personnel in the organization Fortune Commodities \& Derivatives (India) Ltd for this purpose.

Secondary data: As the data relating to commodity and currency prices are of previous years, secondary data is collected. Data is collected for the period from January 2008 to December 2014 on monthly basis. The sources of data are websites, journals and dailies.

\subsection{Conceptual Design}

\section{Sample Unit}

Currency - Euro

Commodity - Gold
ELK Asia Pacific Journals - Special Issue ISBN: 978-81-930411-5-4

Monthly closing price of Euro and Gold spot rate.

Sample size: 7 Years of spot closing price of Euro and gold

Sampling plan: The sampling technique employed was judgmental sampling because the researcher had the liberty of selecting the commodities and the years to consider for arriving the conclusion.

\subsection{RESEARCH INSTRUMENTS}

The collected data has been analyzed using Statistical Techniques to measure return, average return, risk, covariance and coefficient of correlation as follows.

4.3.1 Return: Investor always expects a good rate of return from his investments.

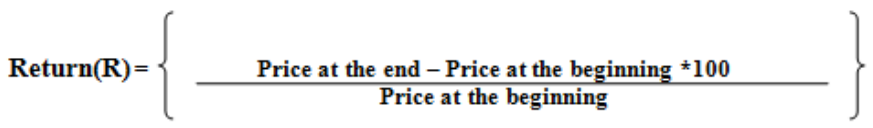

\subsubsection{Average Return: The average is} calculated by combining numbers from the list in a specific way and competing a single number as being the average of the list.

\section{Where, Mean = sum of elements/ number of elements}

$=(\mathbf{a} 1+\mathbf{a} 2+\mathbf{a} 3+\ldots \ldots \ldots \ldots \ldots \ldots$ an $) / \mathbf{n}-1$ Average return $=\Sigma \mathbf{R} /(\mathbf{n}-1)$

\subsubsection{Risk (Standard deviation) :}

Standard deviation is used to 
ELK

Asia Pacific Journals

measure the risk on commodity due

to fluctuation of forex rate.

$\underset{\text { deviation }}{\sigma}$ Standard $\sigma=\sqrt{\frac{\Sigma(R-A r)^{2}}{N-1}}$

4.3.4 Covariance: It measures the variation between gold and US dollar. Positive covariance indicates that asset returns move together and negative covariance shows that returns move inversely.

$$
\begin{gathered}
X=\text { currency } \\
Y=\text { commodity } \\
\text { N }=\text { no of months }
\end{gathered}
$$$$
\mathrm{CoVxy}=\frac{\Sigma(\mathrm{R}-\mathrm{Ar}) \mathrm{x} *(\mathrm{R}-\mathrm{Ar}) \mathrm{y}}{\mathrm{N}-1}
$$

\subsubsection{Coefficient of correlation: It is used} to measure the degree of one variable which is linearly related to another variable. It shows the relationship between Euro and Gold.

Coefficient of correlation (rho) $=\frac{\operatorname{CoV}_{x y}}{\sigma_{x} * \sigma_{y}}$

\subsubsection{VAR (Value at Risk): This}

statistical technique used to measure and quantify the level of financial risk within a firm or investment portfolio over a specific time frame. Variance is used to measure as Finance risk, risk management,
ELK Asia Pacific Journals - Special Issue ISBN: 978-81-930411-5-4

financial control, financial reporting and computing regulatory capital.

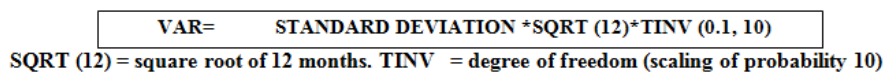

V. Results and Discussion: It helps investors to know the growth rate of Euro and rate of return on gold from the year 2008 to 2014 on monthly spot price basis as follows. 


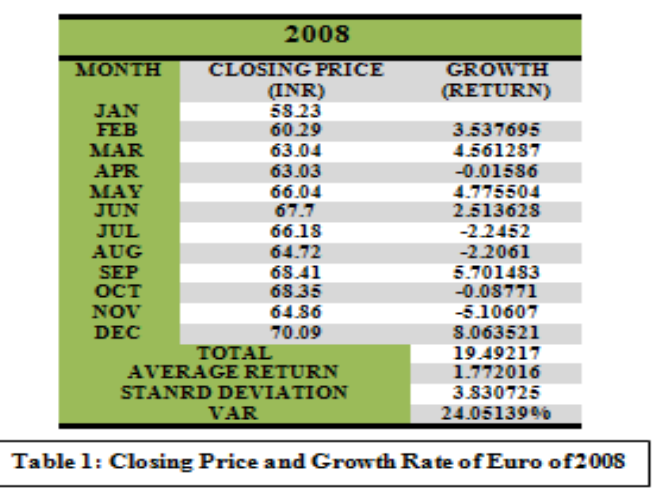

Euro had shown maximum growth of $\mathbf{8 . 0 6}$ in the month of December and negative growth of (5.106) in the month of November and with average growth of $\mathbf{1 . 7 7}$ and standard deviation of 3.83. From the above graph it can be interpreted that Euro return has a

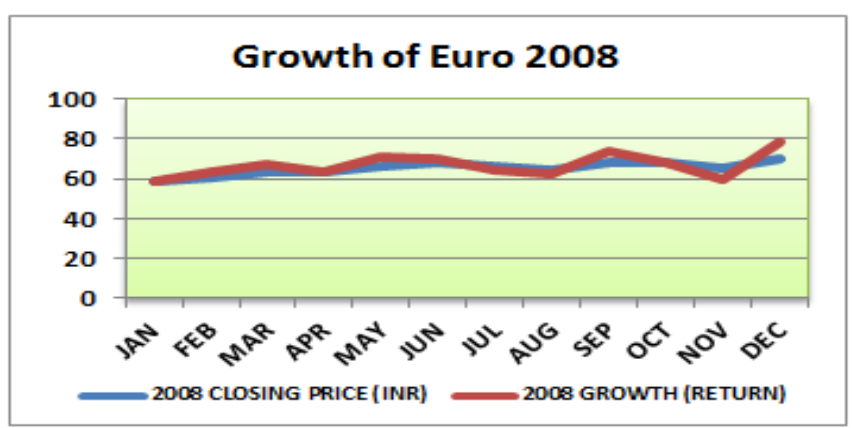

Figure 1: Closing Price and Growth Rate of Euro of 2008 dramatic fluctuation and the risk is $\mathbf{3 . 8 3}$, VAR is $\mathbf{2 4 . 0 5 \%}$. Reasons for this behavior are European sovereign debt crisis was started. Inflation rates were low in the euro zone and there was an external balance was in surplus.

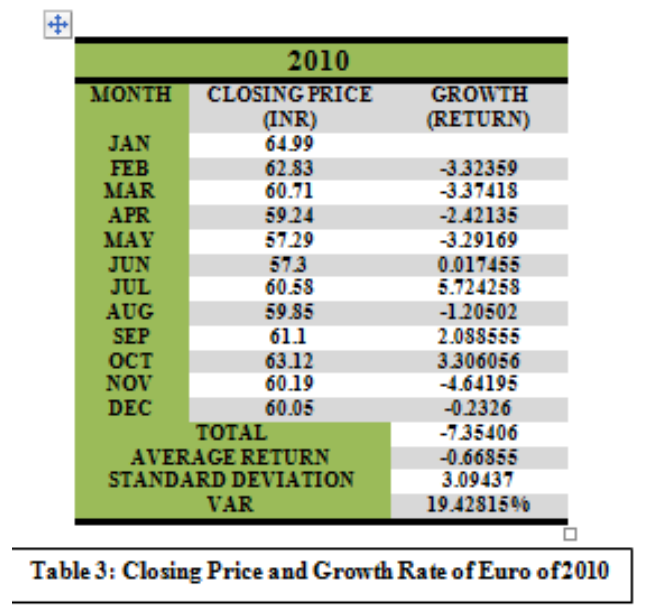

The table reveals that Euro had shown maximum growth of $\mathbf{5 . 7 2}$ in the month of July and negative return (4.642) in the month of November and with the negative average growth of (0.669) and standard deviation of 3.094. From the graph it can be interpreted that EURO return had a positive fluctuation and risk is $\mathbf{3 . 0 9}$ and VAR is

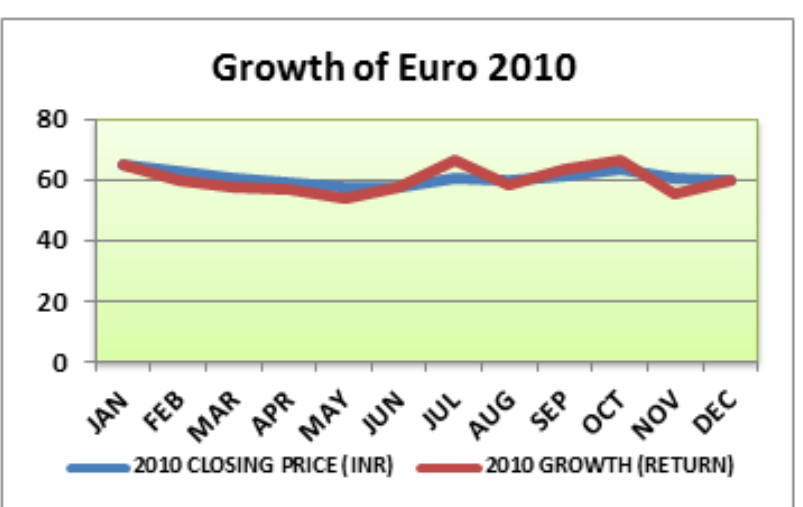

Figure 3: Closing Price and Growth Rate of Euro of 2010

$\mathbf{1 9 . 4 3 \%}$. Average return is $(\mathbf{0 . 6 6 9 )}$. Where has risk increased by $\mathbf{0 . 4 6 \%}$. Reasons for this behaviour are $10 \%$ living in households with very low work intensity. Focus the burden of audit to non-complaint 


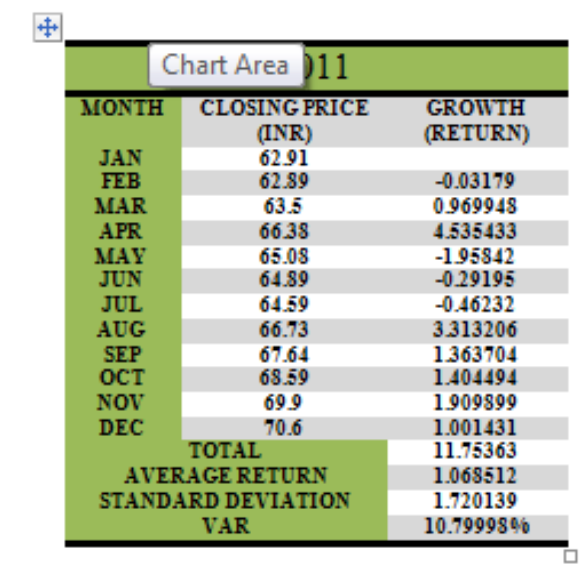

Table 4: Closing Price and Growth Rate of Euro of 2011

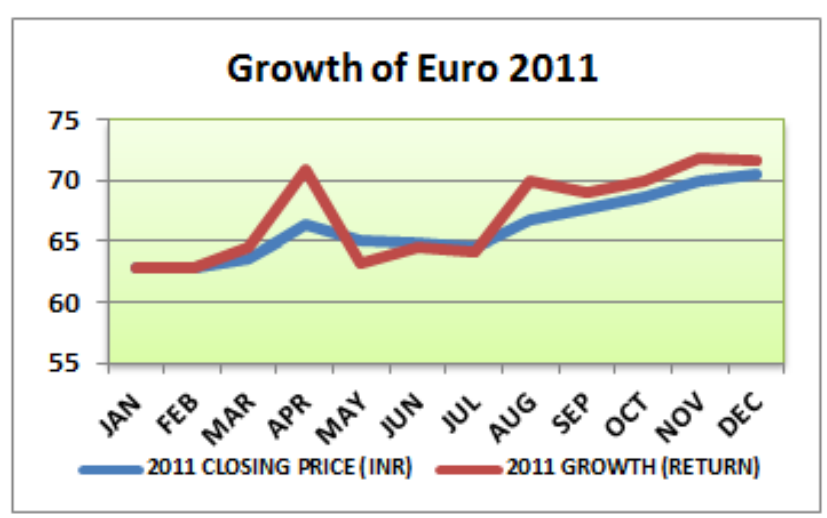

Figure 4: Closing Price and Growth Rate of Euro of 2011

Where the average return is $\mathbf{1 . 0 6 8 5}$ it's increased by $\mathbf{0 . 3 9 \%}$ of 2010 and volatility is 1.72 it's reduced by $1.37 \%$ of 2010 , VAR is $\mathbf{1 0 . 8 0 \%}$. The risk is reduced in this year. Stability fund is not stable and Euro Zone is at risk deviation of 1.720. From the graph it can be Ointerpreted that Euro return had fluctuating.
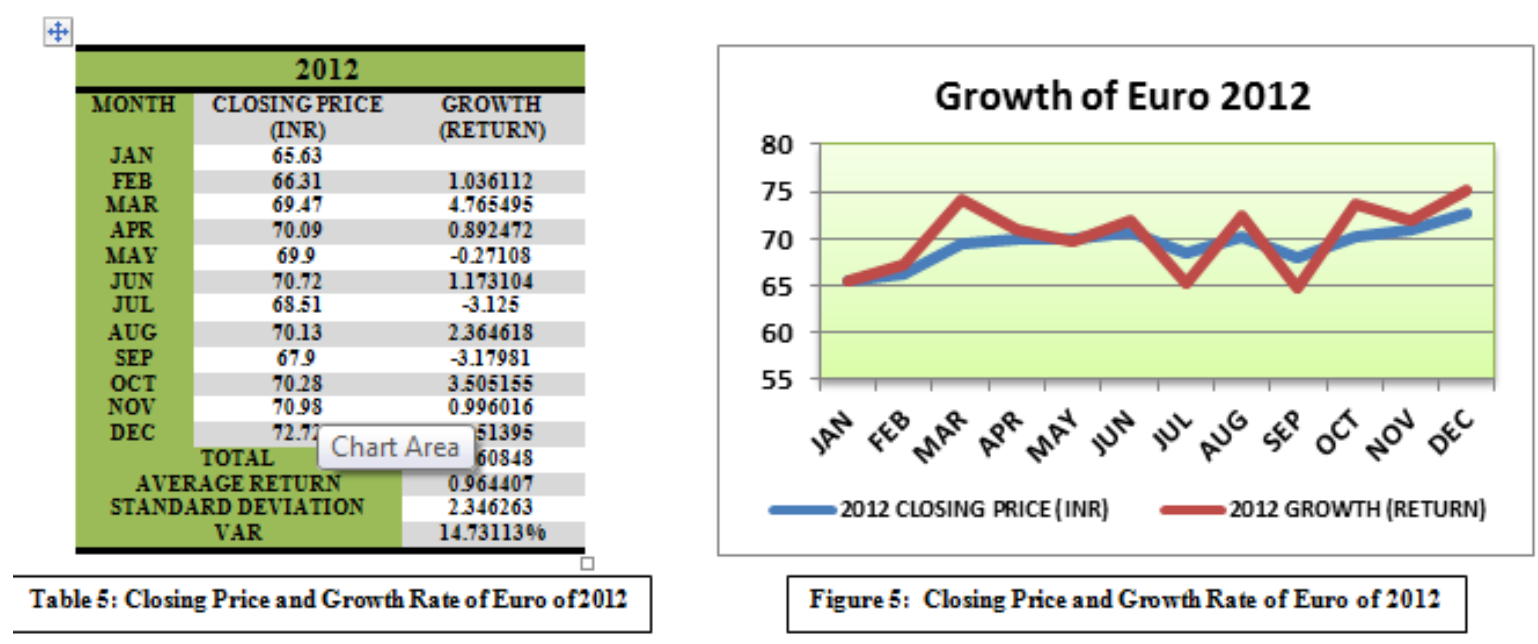

Figure 5: Closing Price and Growth Rate of Euro of 2012 
From the analysis it can be concluded that Euro had shown max return of 4.77 in the month of March and negative return of (3.180) in the month of September. With average return of 0.964 and standard deviation of 2.346. From the graph it can be interpreted that Euro return had a wide fluctuation. Average return is 0.96 it's reduced by $0.1 \%$ of 2011 and volatility is
2.346, VAR is $14.73 \%$. Where the risk is increased by $0.62 \%$.

Reasons for this behavior are the global economy has experienced slow growth since the U.S. financial crisis of 2008-2009, which has exposed the unsustainable fiscal policies of countries in Europe and around the globe. The political implications of the crisis were enormous and conflict over Budget.

\begin{tabular}{|c|c|c|}
\hline \multicolumn{3}{|c|}{2013} \\
\hline MONTH & $\begin{array}{c}\text { CLOSING } \\
\text { PRICE (INR) }\end{array}$ & $\begin{array}{l}\text { GROWTH } \\
\text { (RETURN) }\end{array}$ \\
\hline JAN & 72.22 & \\
\hline FEB & 70.58 & -2.324 \\
\hline MAR & 69.6 & -1.408 \\
\hline APR & 71.01 & 1.986 \\
\hline MAY & 73.54 & 3.44 \\
\hline JUN & 77.34 & 4.913 \\
\hline JUL & 80.69 & 4.152 \\
\hline AUG & 88.18 & 8.494 \\
\hline SEP & 84.36 & -4.528 \\
\hline OCT & 84.2 & -0.19 \\
\hline Nov & 84.82 & 0.731 \\
\hline \multirow[t]{2}{*}{ DEC } & 85.14 & 0.376 \\
\hline & OTAL & 15.642 \\
\hline \multirow{3}{*}{\multicolumn{2}{|c|}{$\begin{array}{l}\text { AVERAGE RETURN } \\
\text { STANDARD DEVIATION } \\
\text { VAR }\end{array}$}} & 1.422 \\
\hline & & 3.6831731 \\
\hline & & $23.12 \%$ \\
\hline
\end{tabular}

Table 6: Closing Price and Growth Rate of Euro of 2013

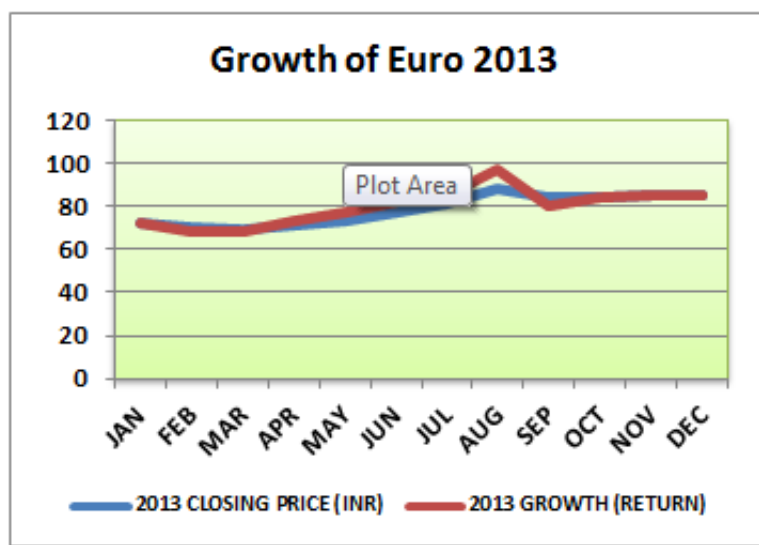

Figure 6: Closing Price and Growth Rate of Euro of 20113
From the above table, it can be analyzed that the returns of Euro had shown max return of 8.494 in the month of Aug and negative return of (4.528) in the month of September. With average return of $\mathbf{1 . 4 2 2}$ and standard deviation of 3.683. From the above graph it can be interpreted that Euro return had a wide fluctuation. Average return is $\mathbf{1 . 4 2 2}$ it's increased by $\mathbf{0 . 4 5 8 \%}$ of 2012 and VAR is
23.12\%. Where the risk is increased by $8.3 \%$. 


\begin{tabular}{ccc}
\hline \multicolumn{3}{c}{2014} \\
\hline MONTH & $\begin{array}{c}\text { CLOSING PRICE } \\
\text { (INR) }\end{array}$ & $\begin{array}{c}\text { GROWTH } \\
\text { (RETURN) }\end{array}$ \\
JAN & 85.44 & \\
FEB & 85.01 & -0.506 \\
MAR & 82.38 & -3.193 \\
APR & 83.2 & 0.986 \\
MAY & 80.72 & -3.072 \\
JUN & 81.92 & 1.465 \\
JUL & 80.46 & -1.815 \\
AUG & 79.49 & -1.22 \\
SEP & 78.11 & -1.767 \\
OCT & 77.48 & -0.813 \\
NOV & 77.53 & 0.064 \\
DEC & 77.45 & -0.103 \\
& TOTAL & -10.038 \\
AVERAGE RETURN & -0.9125455 \\
STANDARD DEVIATION & 1.5014586 \\
\multicolumn{2}{c}{ VAR } & $9.43 \% 0$ \\
\hline
\end{tabular}

Table 7: Closing Price and Growth Rate of Euro of 2014

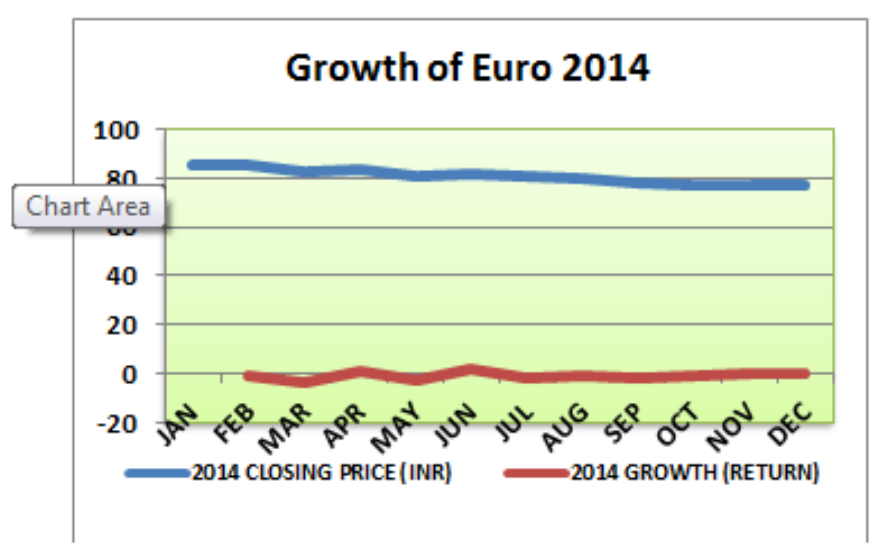

Figure 7: Closing Price and Growth Rate of Euro of 2014
The table reveals that Euro had shown max return of 4.76 in the month of March and negative return of (3.179) in the month of September. With average return of (0.913) and standard deviation of 1.501. From the above graph it can be interpreted that Euro return had a wide fluctuation. Average return is $(\mathbf{0 . 9 1 3})$ it's reduced by $0.51 \%$ of 2013, VAR is $\mathbf{9 . 4 3 \%}$. Where the risk is decreased by $13.69 \%$.
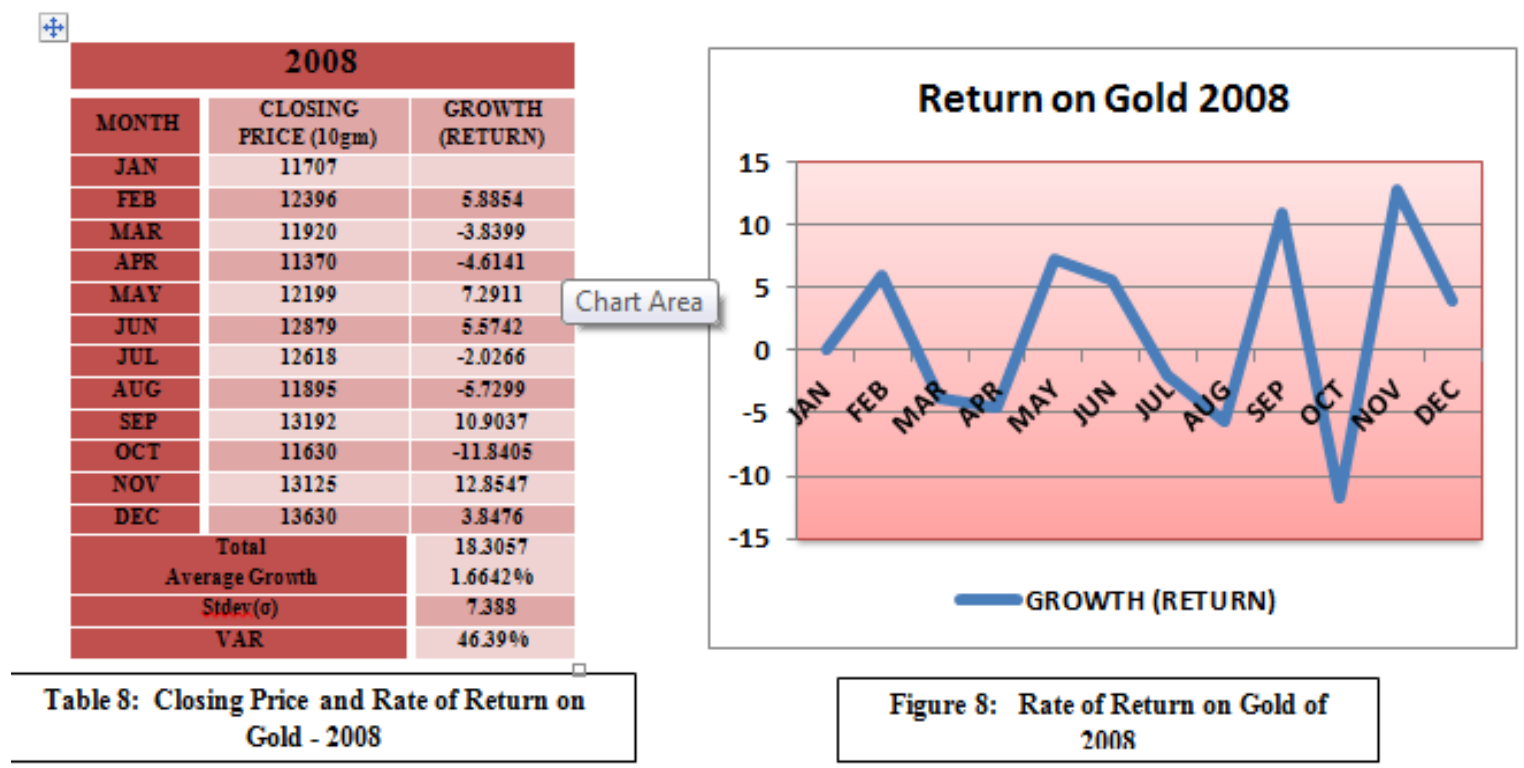
From the analysis it can be concluded that returns on gold had shown max return of 12.85 in the month of November and negative return of (11.84) in the month of October with average return of $\mathbf{1 . 6 6 4}$ and standard deviation of 7.388. From the graph it can be interpreted that returns on gold as a wide fluctuation. The volatility is very high of 9.66 compare to other years and VAR is 46.39\%. Reasons for this behavior are economic crisis in US market, demand pattern changed in Asia and U S market. Less gold jewelery recycling company.

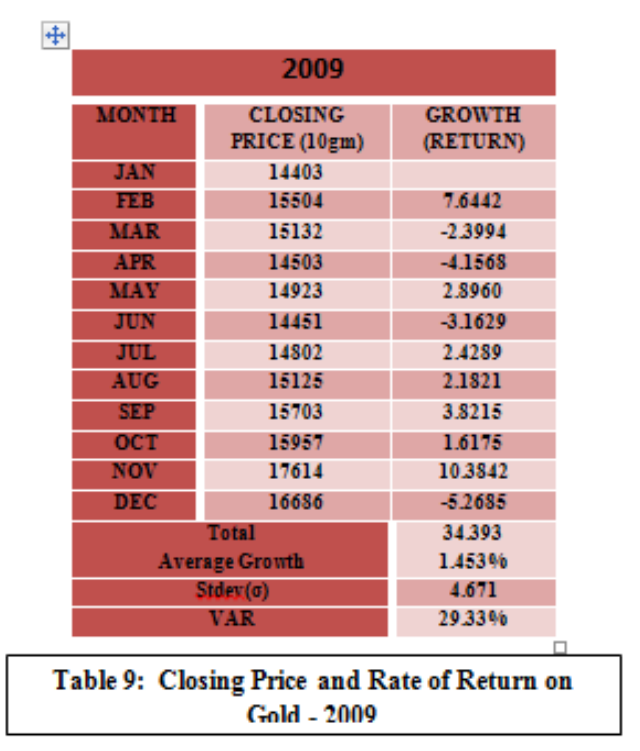

From the above analysis it is observed that return on gold had shown max return of 10.38 in the month of November and negative return of (5.269) in the month of December with average return of $\mathbf{1 . 4 5}$ and standard deviation of 4.67. From the graph it can be interpreted that returns on gold slight fluctuation. The volatility is $\mathbf{4 . 6 7}$ and

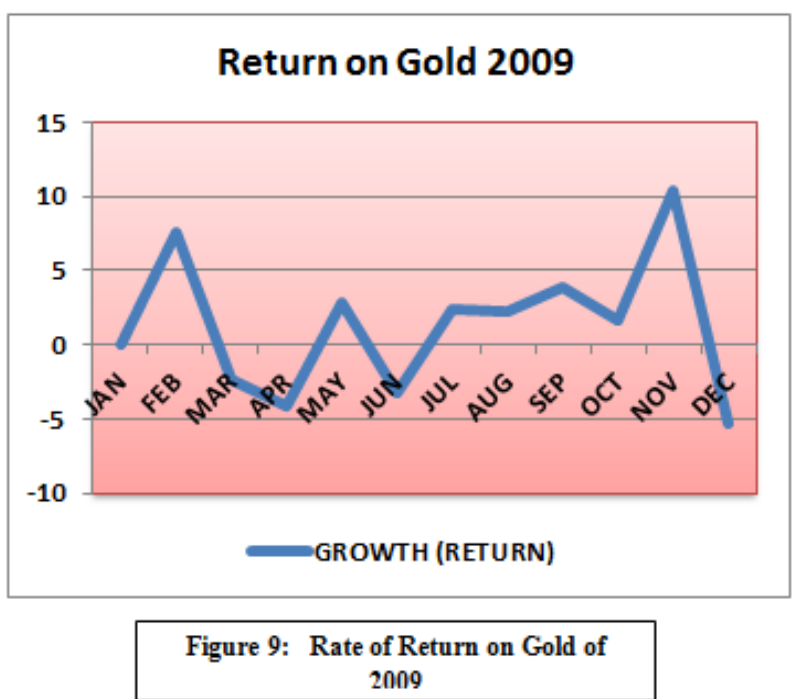

the risk is reducing by $\mathbf{2 . 4 \%}$ compare to 2008 and VAR is $\mathbf{2 9 . 3 3 \% . ~}$ 

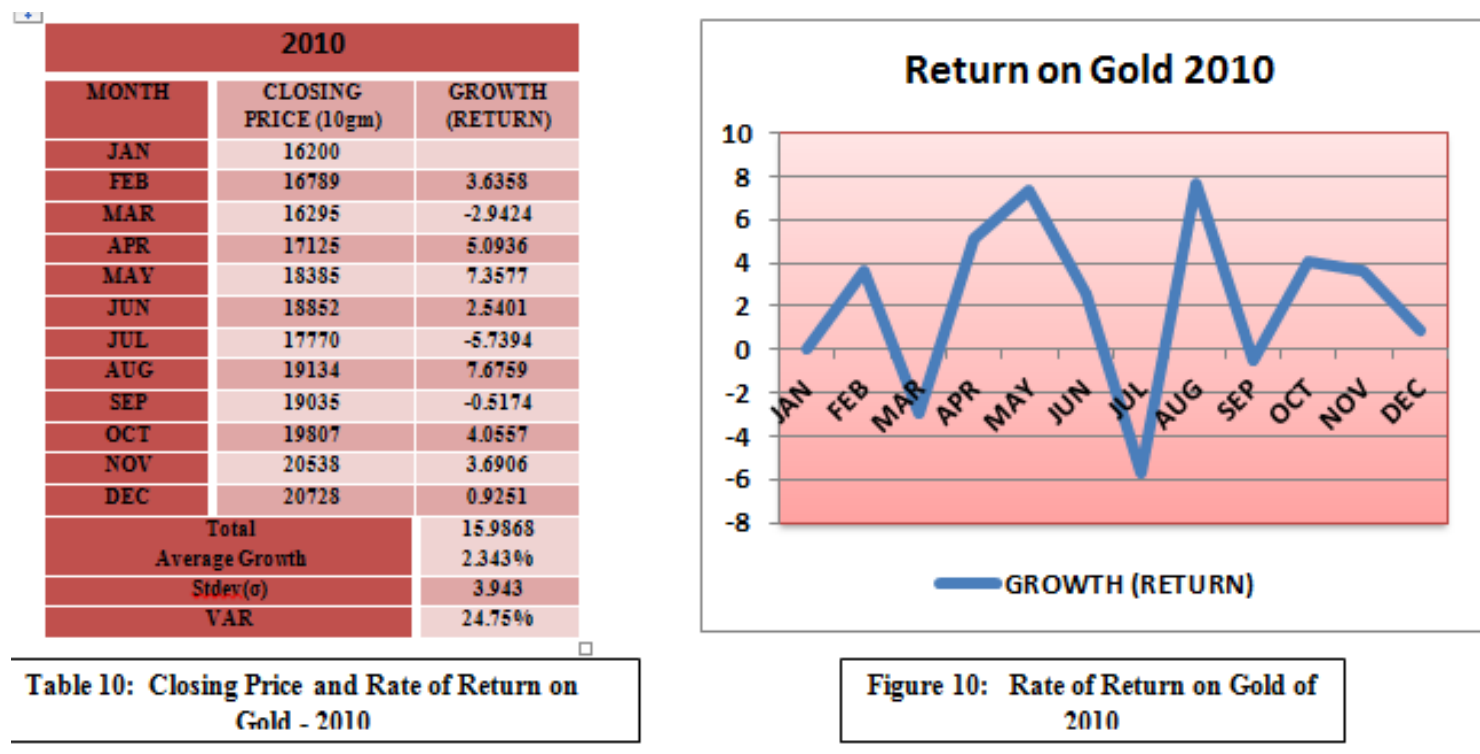

Figure 10: Rate of Return on Gold of 2010

The table reveals that returns on gold had shown max return of $\mathbf{7 . 6 8}$ in the month of August and negative return of (5.74) in the month of July with a negative average return of 2.34 and standard deviation of $\mathbf{3 . 9 4}$. From the graph it can be interpreted that returns on gold had great fluctuation. The volatility is $\mathbf{3 . 9 4 3}$ and the risk isreducing by $1 \%$ compare to 2009 and VAR is $\mathbf{2 4 . 7 5 \% . ~}$ Reasons for this behavior are demand for jewelry and gold bar in India. Economic crisis is reduced in US market and U.S economy was still in recovery stage 

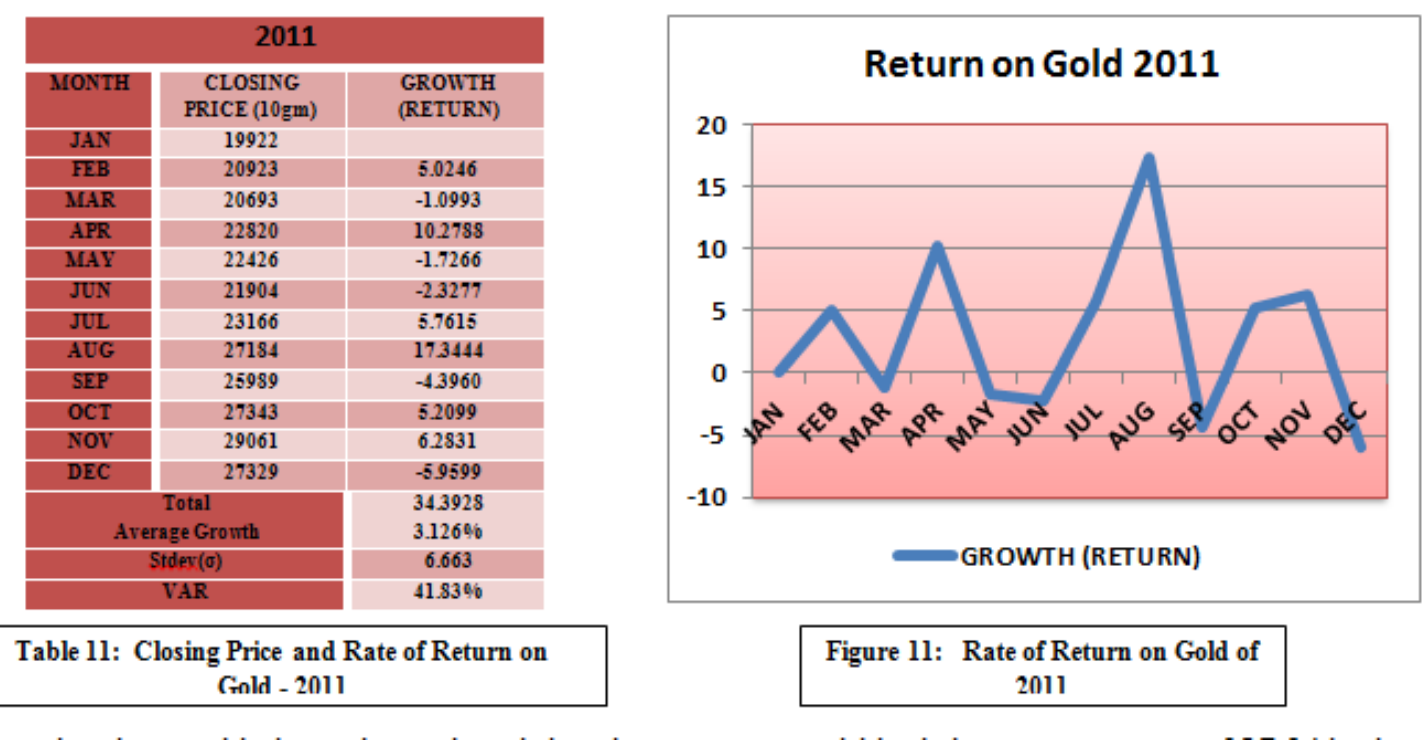

From the above table it can be analyzed that the returns on gold had shown max return of 17.34 in the month of August and negative return of (5.96) in the month of December with average return of $\mathbf{3 . 1 2}$ and standard deviation of 6.66. From the graph it can be interpreted that returns on gold had dramatic fluctuation. The volatility is $\mathbf{6 . 6 6 3}$ risks is double when compared to the last year and VAR is $\mathbf{4 1 . 8 3 \%}$. Reasons for this behavior are limited supply and low output. There was an increase deficit balance in US market. GATA (gold anti-trust action committee) said that Government imposed heavy import tax due to heavy demand for gold bar in India. 

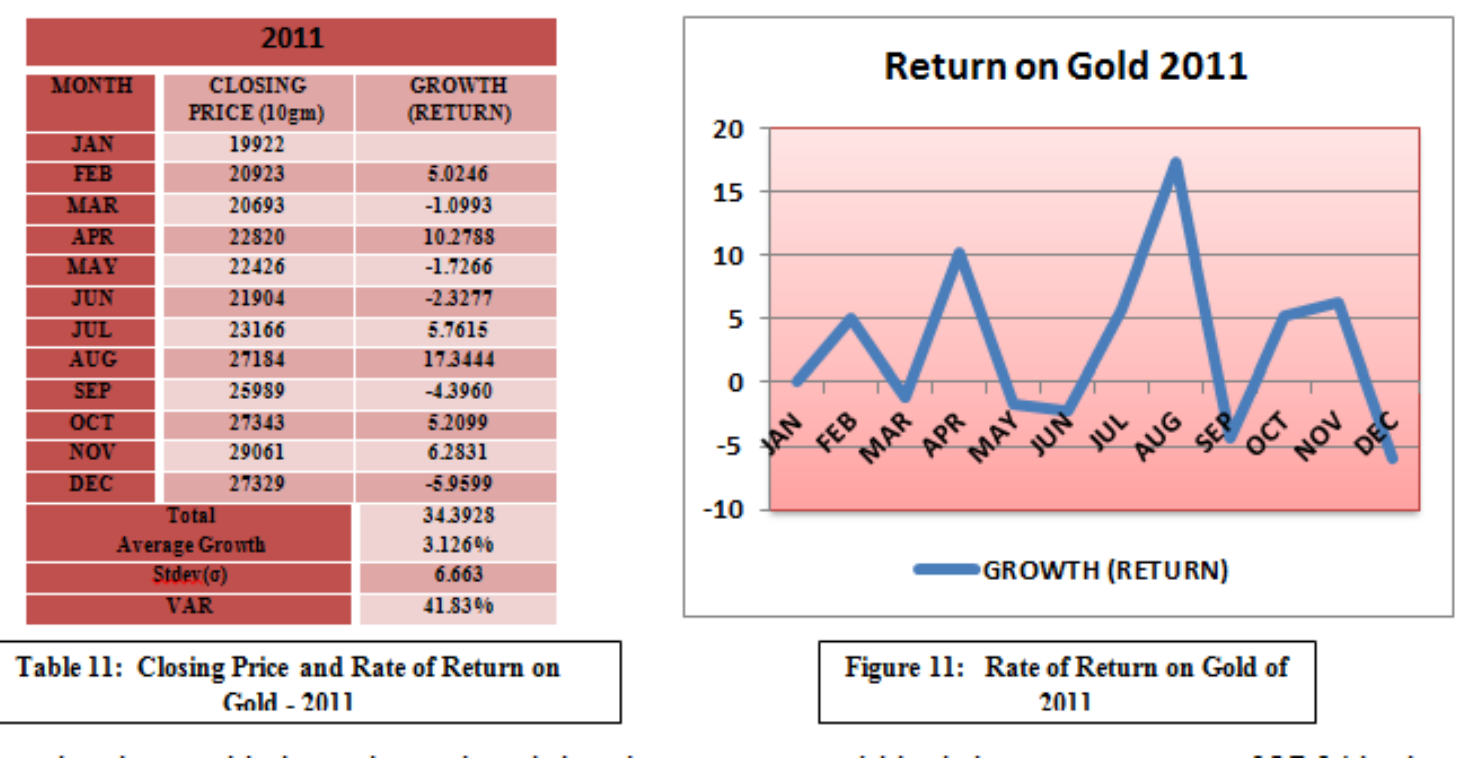

From the above table it can be analyzed that the returns on gold had shown max return of 17.34 in the month of August and negative return of (5.96) in the month of December with average return of $\mathbf{3 . 1 2}$ and standard deviation of 6.66. From the graph it can be interpreted that returns on gold had dramatic fluctuation. The volatility is $\mathbf{6 . 6 6 3}$ risks is double when compared to the last year and VAR is $\mathbf{4 1 . 8 3 \%}$. Reasons for this behavior are limited supply and low output. There was an increase deficit balance in US market. GATA (gold anti-trust action committee) said that Government imposed heavy import tax due to heavy demand for gold bar in India. 


\begin{tabular}{|c|c|c|}
\hline \multicolumn{3}{|c|}{2012} \\
\hline MONTH & $\begin{array}{c}\text { CLOSING } \\
\text { PRICE (10gm) }\end{array}$ & $\begin{array}{l}\text { GROWTH } \\
\text { (RETURN) }\end{array}$ \\
\hline JAN & 28078 & \\
\hline$\overline{\text { FEB }}$ & 27952 & -0.4487 \\
\hline$\overline{\text { MAR }}$ & 28030 & 0.2790 \\
\hline APR & 29183 & 4.1134 \\
\hline$\overline{M A Y}$ & 29148 & -0.1199 \\
\hline JUN & 29665 & 1.7737 \\
\hline JUL & 29749 & 0.2832 \\
\hline AUG & 31206 & 4.8976 \\
\hline SEP & 31201 & -0.0160 \\
\hline OCT & 31105 & -0.3077 \\
\hline NoV & 31076 & -0.0932 \\
\hline $\mathrm{DEC}$ & 30859 & -0.6983 \\
\hline & & 9.6631 \\
\hline & Grouth & $0.878 \%$ \\
\hline & $\overline{v(\sigma)}$ & 1.822 \\
\hline & & 11.4496 \\
\hline
\end{tabular}

Table 12: Closing Price and Rate of Return on Fold - 2012

From the above table, it is observed that the returns on gold had shown max return of 4.89 in the month of August and negative return of (0.698) in the month of December with average return of $\mathbf{0 . 8 7 8}$ and standard deviation of 1.82. From the graph it can be

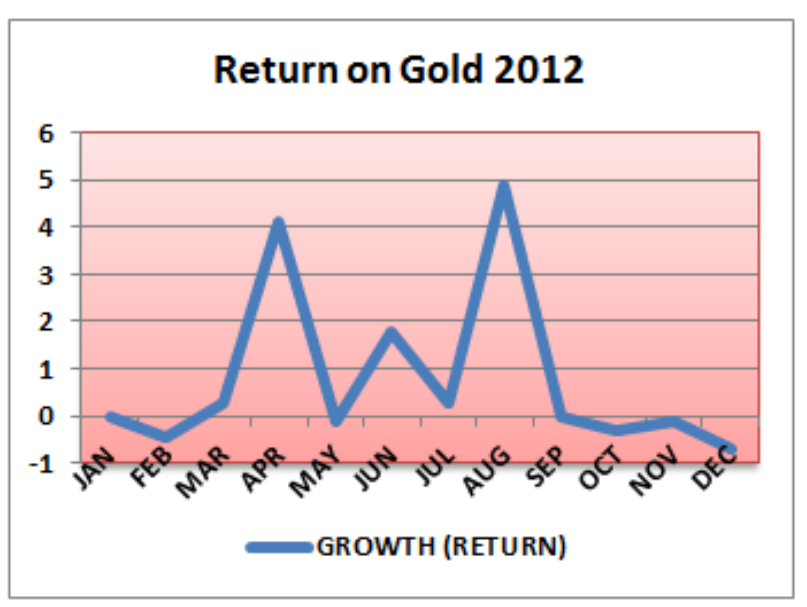

Figure 12: Rate of Return on Gold of 2012

interpreted that returns on gold had slight fluctuation .The volatilityis $\mathbf{1 . 8 2}$, the risk is reduced by $\mathbf{5 \%}$ compare to 2011 and VAR is $\mathbf{1 1 . 4 4 \%}$. Reasons for this behavior are Euro zone crisis started recovering..
¥

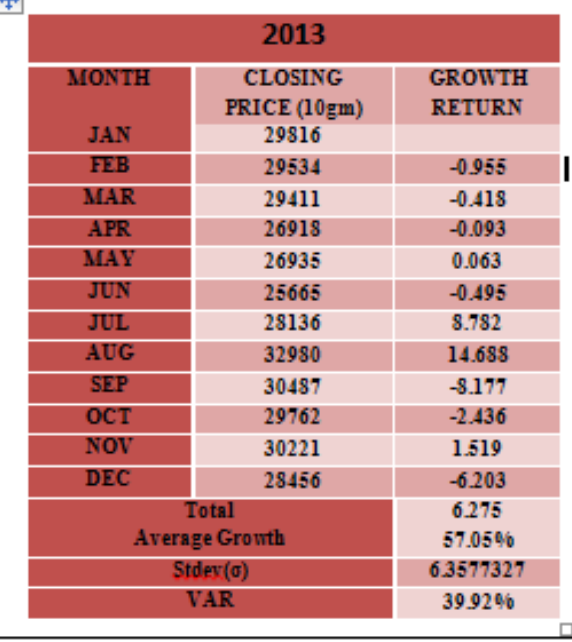

Table 13: Closing Price and Rate of Return on Gold - 2013

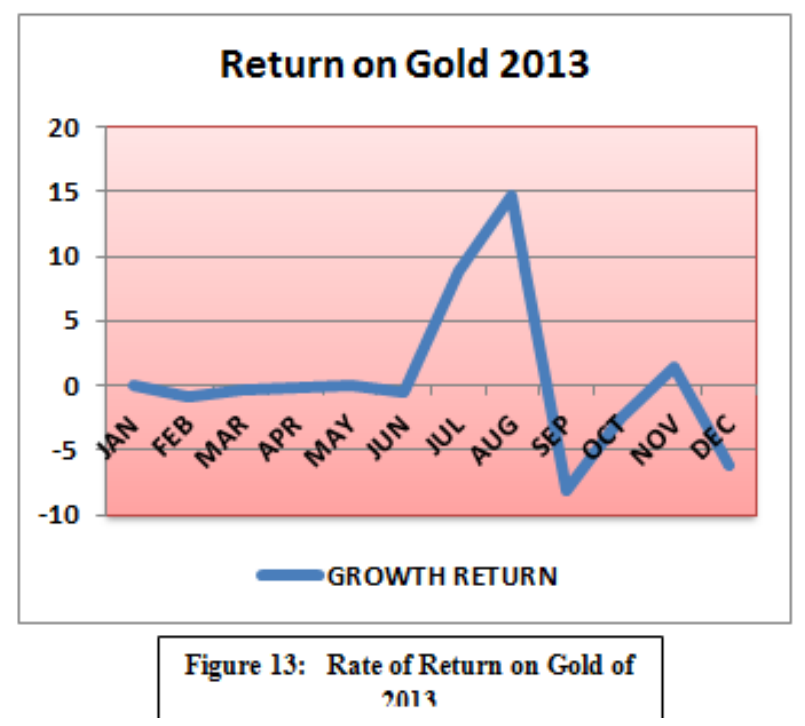


The table reveals that the returns on gold had shown max return of $\mathbf{1 4 . 6 8 8}$ in the month of August and negative return of (8.177) in the month of September with average return of $\mathbf{5 7 . 0 5 \%}$ and standard deviation of 6.358 .
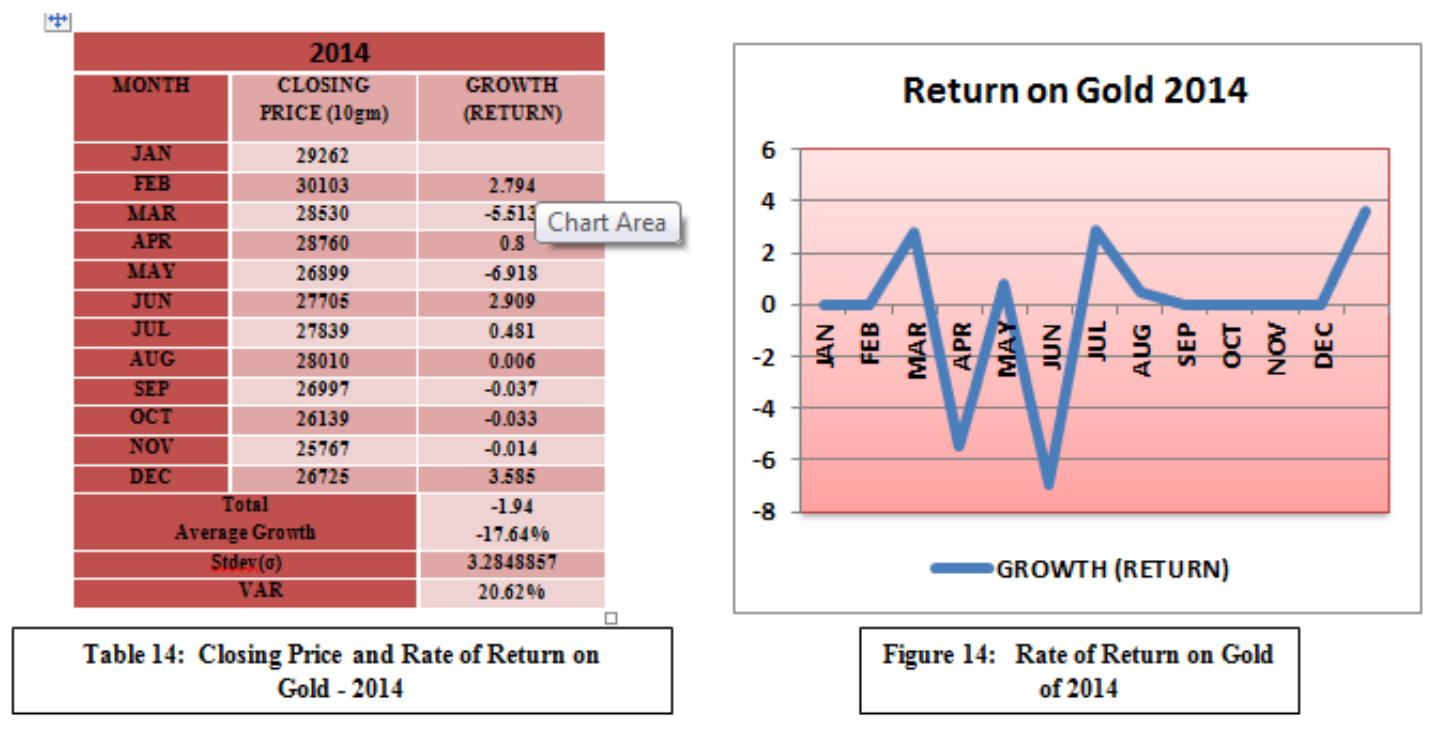

From the analysis it can be concluded that the returns of gold had shown max return 3.585 in the month of December and negative return of (6.918) in the month of May with average return of (17.64) and standard deviation is 3.285. From the graph it can be interpreted that returns of gold had slight fluctuation. The volatility is $\mathbf{3 . 2 8 5}$ and the risk is reduced when compare to 2013 and VAR is $\mathbf{2 0 . 6 2 \%}$.

From the graph it can be interpreted that returns on gold had slight fluctuation. The volatility is $\mathbf{6 . 3 5 8}$ and the risk is double when compare to 2012 and VAR is $\mathbf{3 9 . 9 2 \% . ~}$ 


\section{Co-efficient of correlation between Euro and Gold}

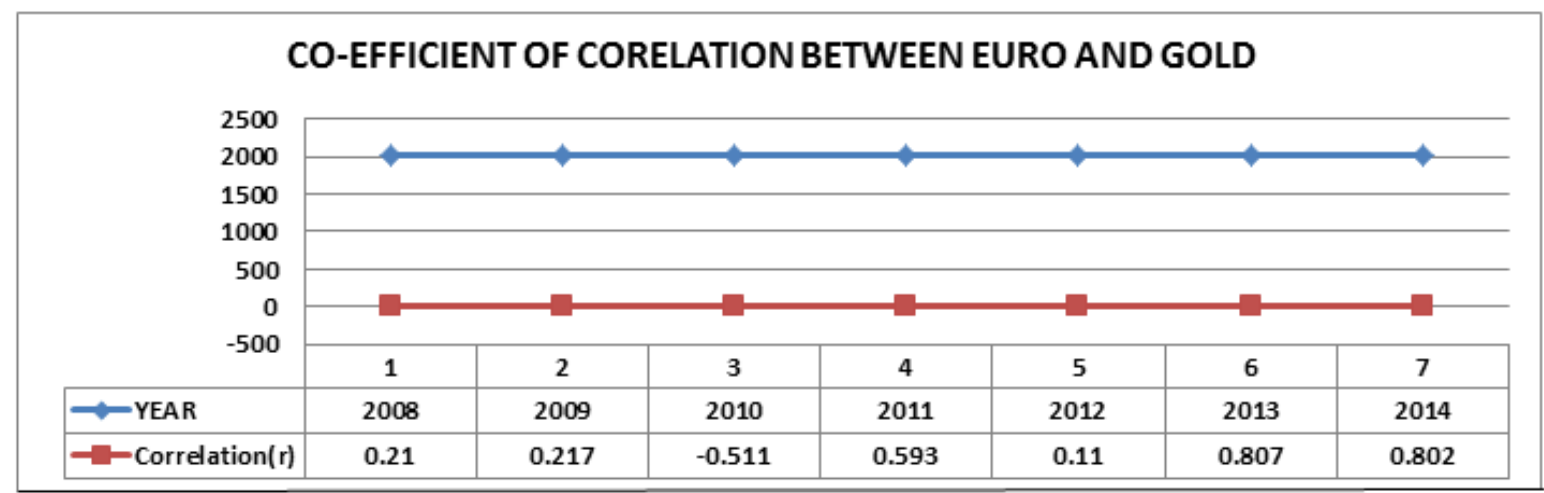

VI. Findings of Analysis and Results

There was positive correlation between the Euro and gold in the year 2008. Hence we can infer that there is a direct relationship between Euro and gold. As and when the Euro value increases there will be simultaneous increase in gold value and vice versa. Due to the recovery of U.S economy euro has been seen by many, as the natural first choice alternative currency to U.S \$ and had benefited from U.S \$ weakness. Gold had been shared a perception of alternative investment to Euro and U.S \$ hence they are related in a positive manner in the year 2009. Negative correlation between Euro and gold was created during 2010. Hence we can infer that there is an inverse relationship between Euro and gold. When Euro value increases there will be simultaneous decrease in gold value and vice versa. Due to the growth of U.S economy both Gold and Euro is treated as alternative investment to the U.S Dollar. Hence they both exist in a positive manner during 2011. The Dollar frequently valued in relation to its main competitor for reserve currency status i.e. Euro. So when the Euro is slammed, the dollar rises and this apparent strength of Dollar makes gold seem less attractive as hedge, and gold sell off. When the acceptance of paper currency and other asset in doubt ultimately gold is considered as safe heaven. During the year 2012 Positive correlation was created between Euro and gold. Positive correlation between Euro and gold was created during 2013 and 2014. During this period direct relationship was 
created between Euro and gold. Euro and gold as a positive correlation. It is wise to invest in euro whenever the growth rate of euro drops downwards. It is not safe to make investment during 2010 because Euro and gold has a negative correlation. Due to political turmoil, long term structural problems took their toll on the European currency hence they both are inversely related

\section{CONCLUSION}

From the above data analysis and discussion it can be concluded that, precious metal gold is performing well from past 7 years compare to the foreign currency of Euro. It was observed during the study that there exist a relationship between commodities and foreign currencies. This relationship is expressed as positive or negative correlation. Gold and Euro as a positive relationship. An investor can make use of this study to make prudent investment in commodities based on the relationship between exchange rates and commodity. Macro factors influencing the appreciation and deprecation of their values. From the above analysis it can be inferred that there exists positive correlation between the EURO and gold. Hence we can infer that there is a direct relationship between EURO and gold. This means when euro value increases there will be simultaneous increase in gold value and vice versa. This study enables to know how much risk will be involved to the investors while investing on commodities and currencies with the help of value at risk. The behavior of Euro growth rate from 2008 to 2014 had stable grow rate and in 2010 there was a negative growth. Examine the behavior of gold price from 2008 to 2014 reveals that gold price accelerated from $11 \%$ in 2008 to $41 \%$ in 2014, there after it tended to stabilized. The relationship between euro and gold has been positive. This implies that as rupee depreciates against euro the price of gold goes up.

\section{Reference}

[1] Security Analysis and Portfolio Management - Punithavathy Pandain , 2/e, 2005

[2] Bose, S., (2008),"Commodity Futures Market in India: A Study of Trends in the National Multi Commodity, Indices", Money and Finance, Vol.20, No.pp.125-158.

[3] Ederington, LH (1979)" Hedging Performance of the New Futures Markets", The Journal of Finance, Vol.36, No.pp.157-170. 
[4] Haque K (2008), Hedging against commodity Volatility" www.cpoagenda.com

[5] US Dollar (USD) to Indian Rupee (INR) exchange rate history viewed spot closing price on monthly basis from January 2008 to December 2014.

[6] Investment Management Security Analysis and Portfolio Management - V.K.BHALLA

First Edition 1982, Subsequent Editions and Reprinting

[7] Fundamentals of Statistics - S.C Gupta, Himalaya Publishing House, 6/e, 2004

[8] Quantitative Techniques for Business Decisions-C.M.Chikkodi,

B.G.Satyaprasad,Amit Kumar C.Chikkodi, Himalaya Publishing House, 2014

[9] Business Statistics-Dr.Alice ManiSapna Book House

[10] Quantitative Methods for Business-

S.L.Aggarwal(LUDHIANA), S.L.Bhardwaj(PATIALA), Kalyani Publishers

[11] Amit Kapoor(2007) "Rising Rupee and India Growth Story", the Economic Times, August 29

[12] C.R.L.Narasimhan", The Hindu, April 32003.

[13] Engel, R.F., T.Ito and W.L. Lin (1990), "Meteor showers or heat waves? Heteroskedastic intra-daily volatility in the foreign exchange market", Econometrica, 58 (3) , 525542.

[14] Gray Shoup (2006) "Foreign Currency Management", Published by infinity Groups. [15] shankar Acharya (2007) "Exchange
Rate Policy", Business Standard, April 26. 